\title{
Separation of magnetite concentrate before the last grinding stage
}

\author{
Aleksei Pelevin *, Vil Saitov, and Vladimir D mitriev \\ U ral State M ining University, 620144, 30, K uibyshev st., Ekaterinburg, Russia
}

\begin{abstract}
For magnetite and titanium magnetite ores, it is possible to use technology with the separation of concentrate before the last grinding stage. The possibility of staged separation of iron concentrate is due to different physical-mechanical properties of magnetite and rock minerals. The results of industrial and laboratory tests on the use of special magnetic separators with special structure, Derrick screen and screw separators in iron ore dressing schemes are presented. A comparison of proven dressing methods is performed. The choice of a specific dressing method for the staged separation of magnetite concentrate before the last grinding stage is determined by the properties of the base ore and the economic justification.
\end{abstract}

To enrich magnetite ores, magnetic dressing schemes with staged tailings separation are used after each grinding stage. For this, wet magnetic separation in a low intensity magnetic field (Wet-LIMS) is used. Iron concentrate is obtained after the last grinding stage. The technology of stage ore dressing consists in separation after each operation of reducing the fineness of finished products (concentrate or tailings). The main input in ore dressing comes to grinding. The reduction in the mass of the product fed to grinding leads to an increase in the economic indicators of ore dressing.

For magnetite and titanium magnetite ores, technologies with stage separation of concentrate are applicable. The possibility of staged separation of iron concentrate is due to different physical-mechanical properties of magnetite and rock minerals. It is better to separate the concentrate before the last grinding stage (Fig. 1). As the dressing operation, the following can be applied:

- magnetic dressing in separators of a special structure;

- hydraulic screening on sieves $0.075-0.3 \mathrm{~mm}$;

- gravitational dressing in screw separators.

\section{Application of separators with special structure}

The tests were performed on two types of drum magnetic separators. Separator No. 1 has a magnetic system that creates a constant magnetic field. The design of the separator bath No. 1 makes it possible to separate the initial product by magnetic properties and size [1]. Separator No. 2 has a rotating permanent magnetic system with constant magnets located

\footnotetext{
${ }^{*}$ Corresponding author: a-pelevin@yandex.ru
} 
inside the stationary drum. The rotation of the magnetic system creates a variable magnetic field in the separation zone [2]. The test results of magnetic separators with special structure in dressing operation to produce concentrate No. 1 (Fig. 1) are shown in Table 1.
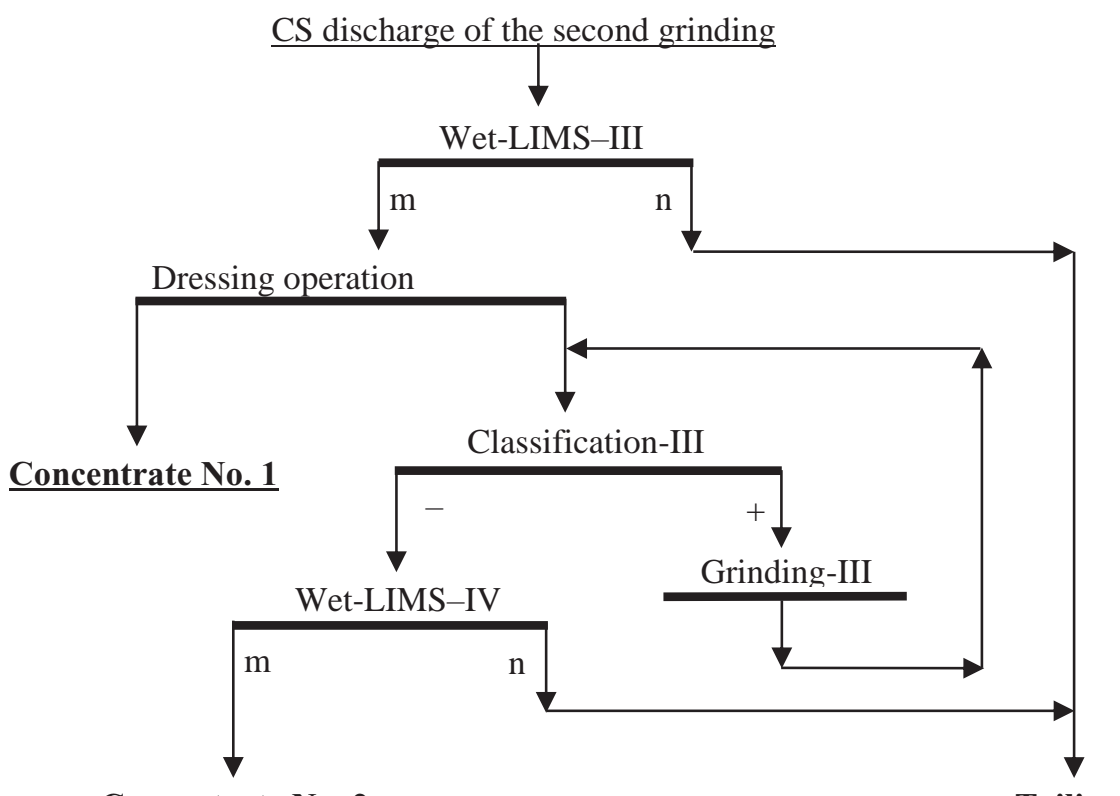

Concentrate No. 2

$\underline{\text { Tailings }}$

Fig. 1. Scheme of concentrate separation before the third stage of grinding.

Table 2. Results of titanium magnetite concentrate No. 1 separation using magnetic separators and using hydraulic screening (Fig. 1)

\begin{tabular}{|c|c|c|c|c|}
\hline \multirow{2}{*}{ Product } & \multirow{2}{*}{$\begin{array}{l}\text { Output to } \\
\text { operation, \% }\end{array}$} & \multicolumn{2}{|c|}{ Weight content, $\%$} & \multirow{2}{*}{$\begin{array}{l}\text { Fe separation to } \\
\text { operation, \% }\end{array}$} \\
\hline & & $\mathrm{Fe}$ & class $-0.071 \mathrm{~mm}$ & \\
\hline \multicolumn{5}{|c|}{ Separator No. 1, industrial testing [1] } \\
\hline Magnetic & 22.2 & 61.8 & 59.4 & 23.1 \\
\hline Non-magnetic & 77.8 & 58.6 & 55.8 & 76.9 \\
\hline Primary & 100.0 & 59.3 & 56.6 & 100.0 \\
\hline \multicolumn{5}{|c|}{ Separator No. 2, laboratory tests } \\
\hline Magnetic & 81.5 & 61.1 & 57.8 & 87.2 \\
\hline Non-magnetic & 18.5 & 39.4 & 55.1 & 12.8 \\
\hline Primary & 100.0 & 57.1 & 57.3 & 100 \\
\hline \multicolumn{5}{|c|}{ Derrick screen, sieve size $0.15 \mathrm{~mm}$, industrial tests [1] } \\
\hline Undersize & 50.8 & 62.0 & 79.9 & 54.3 \\
\hline Oversize & 49.2 & 53.9 & 33.6 & 45.7 \\
\hline Primary & 100.0 & 58.0 & 57.1 & 100.0 \\
\hline
\end{tabular}

Yield of concentrate (magnetic product) during industrial testing of separator No. 1 was $22.2 \%$ (Table 1). The staged separation of concentrate No. 1 allowed to reduce the amount of product entering the third grinding stage by $22.2 \%$ (Fig. 1). The weight content of the class $-0.071 \mathrm{~mm}$ in the magnetic product increased by $2.8 \%$. Fe weight content in the supply of the third stage of grinding (in a non-magnetic product) did not significantly decrease. 
Yield of concentrate (magnetic product) during laboratory testing of separator No. 2 was $81.5 \%$ (Table 1). The stage separation of concentrate No. 1 using a separator with the variable magnetic field can significantly reduce the amount of product entering the third grinding stage (Fig. 1). The weight content of the class $-0.071 \mathrm{~mm}$ in the magnetic product increased by $0.5 \%$. Fe weight content in the supply of the third stage of grinding (in a nonmagnetic product) reduced significantly $(39.4 \%)$. The dressing results for the separation of the concentrate before the last grinding stage are better when using separator No. 2, compared with separator No. 1 (Table 1).

\section{Application of hydraulic screening}

Theory and practice of using hydraulic screening on $0.075-1 \mathrm{~mm}$ sieves in grinding and dressing schemes has been sufficiently studied [3-6]. The test results of Derrick screen in dressing operation to produce concentrate No. 1 (Fig. 1) are shown in Table 1. The Derrick screen sieve mesh size was $0.15 \mathrm{~mm}$. Undersize product Derrick screen was additionally exposed to magnetic separation. The yield of concentrate (undersize product) during industrial tests of Derrick screen was $50.8 \%$ (Table 1). The staged separation of concentrate No. 1 allowed to reduce the amount of product entering the third grinding stage by $50.8 \%$ (Fig. 1). The weight content of the class $-0.071 \mathrm{~mm}$ in the undersize product increased by $79.9 \%$. Fe weight content in the supply of the third stage of grinding (in oversize product) did not significantly decrease.

\section{Screw separation application}

The theory and practice of using screw separation in grinding and dressing schemes has been studied quite extensively [7-11]. The results of the magnetite ore dressing according to the existing scheme and according to the scheme with the use of screw separation to separate concentrate No. 1 (Fig. 1) are shown in Table 2.

Table 2. Magnetite ore dressing results using screw separation to separate concentrate No. 1 (Fig. 1)

[11]

\begin{tabular}{|l|c|c|c|}
\hline \multicolumn{1}{|c|}{ Product } & $\begin{array}{c}\text { Output to ore, } \\
\%\end{array}$ & Fe weight content, \% & Fe separation to ore, \% \\
\hline \multicolumn{4}{|c|}{ Existing scheme, industrial tests } \\
\hline Concentrate & 60.6 & 61.7 & 89.7 \\
Tailings & 39.4 & 10.9 & 10.3 \\
\hline Primary & 100.0 & 41.7 & 100.0 \\
\hline \multicolumn{4}{|c|}{ Scheme with the use of screw separation, industrial tests } \\
\hline Concentrate No. 1 & 21.5 & 63.1 & 32.5 \\
Concentrate No. 2 & 40.2 & 60.9 & 58.7 \\
\hline Total concentrate & 61.7 & 61.7 & 91.2 \\
\hline Tailings & 38.3 & 9.6 & 8.8 \\
\hline Primary & 100.0 & 41.7 & 100.0 \\
\hline
\end{tabular}

During industrial tests, a concentrate (heavy product) with an iron weight content of $63.1 \%$ was obtained with an output of $21.5 \%$ to ore and iron extracted into a concentrate of $32.5 \%$ to ore. Compared to the standard scheme, the total yield of concentrate increased by $1.1 \%$, and the extraction of iron into concentrate increased by $1.5 \%$ (Table 2 ). 


\section{Conclusion}

The test results showed the possibility of using magnetic dressing in separators of a special structure, hydraulic screening and screw separation for the staged production of concentrate before the last grinding stage. The possibility of staged separation of iron concentrate is due to different physical-mechanical properties of magnetite and rock minerals.

The best results were achieved using the separator No. 2 with the variable magnetic field. However, the results were obtained in laboratory tests. Variable magnetic field separators are not widely used. This is due to the complex structure, low productivity and size limitations of the primary product.

Application of Derrick screen allows to achieve high results. However, the price of Derrick screen is the highest among the devices in question. When using Derrick screen, it is necessary to change the screens often.

The use of magnetic separator No. 2 and screw separators allows to separate a smaller amount of concentrate No. 1 before the last grinding stage compared to Derrick screen. However, these technologies will require lower cash costs for implementation.

The applicability of a specific dressing method for the staged separation of concentrate before the last grinding stage is determined by the properties of the base ore and the economic justification.

\section{References}

1. A. E. Pelevin, N. A. Sytykh, Obogashchenie rud, 4, 10 (2016)

2. A. E. Pelevin, Obogashchenie rud, 6, 19 (2019)

3. D. Markauskas, H. Kruggel-Emden, Advanced Powder Technology, 30(12), 2997 (2019)

4. S. Palaniandy, R. Halomoan, H. Ishikawa, Minerals Engineering, 133, 10 (2019)

5. L. A. Vaisberg, A. N. Korovnikov, Obogashchenie rud, 3, 23 (2004)

6. A. E. Pelevin, N. A. Sytykh, Obogashchenie rud, 2, 13 (2018)

7. J. D. Grobler, N. Naudé, J. H. Zietsman, Minerals Engineering, 92, 189 (2016)

8. P. K. Jain, V. Rayasam, Powder Technology, 308, 165 (2017)

9. E. C. Nienaber, J. T. McCoy, L. Auret. IFAC-PapersOnLine, 50(2), 53(2017)

10. M. Sadeghi, C. Bazin, M. Renaud, International Journal of Mineral Processing, 153, 51 (2016)

11. S. A. Prokopyev, A. E. Pelevin, S. A. Napolskikh, R. A. Gelbing, Obogashchenie rud, 4, 28 (2018) 